ichthyological papers, "Type in Paris; cannot be found". Under Prof. Bertin the types were found and catalogued. Five fascicles of this catalogue have been published by the Museum, and Unesco funds were to have been made available for the rest.

Bertin developed a talent for popularization. The biggest work of this kind from his hand is "La Vie des Animaux" (1949-50). His contribution to the "Traité de Zoologie" is now in the press and due to appear shortly; so, too, is an English edition of "Les Anguilles".

Bertin served his country as a soldier in both World Wars, and received the Croix de Guerre for courage under bombardment in 1940. A man of distinguished appearance, his personality was dynamic and gay, and it is this that gives a special sadness to his sudden and tragic end. He leaves a widow and three children.

E. Trewavas

\section{Prof. E. D. Merrill}

Elmer Drew MerRili was born on October 15, 1876, in a village near Auburn, Maine; there he grew up amid country sights and sounds. From the village school he passed to a high school in Auburn, walking the three miles in all weathers; and finally to the State College in Orono, which during his years became the University of Maine. $\mathrm{He}$ has written that his biological teacher roused his enthusiasm for field work; but the love of the wilds was already in him : late in life the Maine woods continued to attract him. He was compelled to earn as he learned, serving, for example, as a student-assistant in the botanical laboratory. Having graduated B.S. in 1898, he held minor appointment until in the next year he was appointed an assistant agrost. ologist in the Dopartment of Agriculture at Washington.

Morrill's excursions in Maine had provided bim with a small collection of about a thousand dried plants; and his first entrances into print were records of Maine plants. Three years at Washington led to half a dozen short papers on grasses, along with a valuable training in method. Unexpectedly, he was offered the post of Government botanist in the Philippine Islands. He demurred as untrained for such a responsibility; but it was pressed on him and he arrived in Manila in March 1902, having visited the botanical establishments in Ceylon and Singapore on the way. His beginnings were certainly an adventure : an unfurnished room awaited him. The herbarium of Philippine plants, made by Vidal and nomenclaturally co-ordinated at Kew, had been destroyed in 1897 by an accidental fire; a second herbarium which would have thrown light on the naming in the third edition of Blanco's "Flora" had been destroyed in the fighting of 1899. Such books as there had been, if not burned, had been purloined; and he started from scratch. In twenty-two years his new herbarium grew into a splendid collection of 270,000 mounted sheets and he would have written a descriptive "Flora" had he been left with the opportunities. He had travellod in all parts of the Archipelago, had had loyal support from forest officers and others interested in plants and had made very effective use of trained Filipino collectors. His office methods were direct and purposeful ; and as no flora can be studied profitably in isolation he had extended his collecting of data to surrounding lands.
This collection was destroyed by the Japanese. It had held the reference material for a vast output of taxonomic papers; but the magnitude of the loss on its destruction is lessened by the existence of duplicates in many herbaria which he, thinking internationally, had distributed abundantly.

As a prelude to the projected Flora of the Archipelago, he published in 1912 a descriptive "Flora of Manila" to support teaching in the University, and to teach was immediately added to his duties. In 1919 a further portion of his time was withdrawn from botanical research, for he was required to take the post of director of the Bureau of Science. His reaction to added work was to lengthen the day; but he could and did turn the projected descriptive "Flora" into an "Enumeration of Philippine Flowering Plants", which appeared during 1923-26, the fourth and last volume holding a masterly phyto. geographical review.

Merrill had married in 1907, and for the sake of the children a home was made in the United States; he spent part of his leave in 1921 with them in California, returning to Manila alone. In 1923 the University of California offered him the appointment of dean of its College of Agriculture. He accepted and served there for five years. Then he was invited to be director of the New York Botanic Garden, and he also served there for five years. In 1935 he was asked to take the post of administrator of the Collections of Harvard University (otherwise director of the Arnold Arboretum), which he held for eleven years. All three posts were difficult by reason of conflicting interests ; but he was remarkably successful in all of them. One who knew him intimately wrote of his qualities-quickness of perception, unfailing patience and courtesy, great store of common sense, promptness in taking action, approachableness, and consideration for others. The University of California at Berkeley joked about his early hours used in naming collections that followed him from Manila. His reliability drew unexpectedly large donations towards his projects. In New York during the distressing slump of 1930 as many unemployed stenographers as he could employ were put at his service, and he used their labour for the innovation of incor. porating descriptions and illustrations among the herbarium sheets. The Harvard University units that wore under his charge were commonly spoken of as the 'orphans'. His first annual report referred to the need of somehow placing them in the 'family'; but re-organization was deferred until after his retirement. His last annual report gives a retrospect, of his eleven years and shows the orphans, though still orphans, growing healthily.

In advance of his seventieth birthday Merrill was released on request from administrative duties at the end of the Arboretum's fiscal year (June 30, 1946). He remained Arnold professor of botany and continued his botanical work. The dispersal of cultivated plants had become a major interest. He had criticized in 1920 the extravagant diffusion theories of $\mathrm{O} . \mathrm{F}$. Cook, and later, when at New York, had had occasion to attack fresh unsubstantial claims of pre-Columbian. transfers of useful plants between the Americas and the rest of the world. In 1950 in Washington. anthropological friends asked him to sum up the case against new diffusionists, and shortly afterwards: one of the diffusionists challenged him to prove his position. In the next year, being in London and at work on plant distribution, it occurred to him that, as the introduction of weeds offers eviderco 
parallel to the introduction of cultivated plants, he could use the old records in the British Museum for his purpose, and he began to write his last book, "The Botany of Cook's Voyages". Unfortunately he was taken ill and the work was interrupted; he recovered and resumed it, but was taken ill again. At a second resumption he completed the writing, and with the help of others the book was published in the autumn of 1954 , by which time he was exceedingly ill; but he lived to February 25 of this year. $\mathrm{He}$ had received many honours and had obtained an international position in his own branch of botany that was unmatched. I. H. BuRkILI

\section{Sir Cyril Norwood}

WIтH the death of Sir Cyril Norwood on March 13, at the age of eighty, there passed an outstanding figure in the world of education of the past fifty years. His influence was comparable to that of men like Arnold in the nineteenth century. Norwood, a brilliant classical scholar from Merchant Taylors' School, gained the highest honours at Oxford and spent several years in the Home Civil Service before entering the teaching profession at Leeds Grammar School in 1901. Five years later he became head. master of Bristol Grammar School, and during fifteen years he transformed its standards and achievements. Then followed nine years, perhaps the zenith of his school activities, as master of Marlborough College, before his migration to the headmastership of Harrow and in 1934 to the presidency of St. John's, Oxford, his former College, from which he resigned in 1946 because of his wife's ill-health.

Throughout his whole educational career, Dr. Norwood brought what has been called the 'modern approach' to bear upon the organization concerned. Without relinquishing his firm belief both in the value of a classical training for the study of language and in the study of ancient history, he was among the first to emphasize the need for a greater emphasis on the teaching of modern languages, geography, science, and later of economics. His underlying aim seemed to be to modify where necessary an existing system of education-sometimes stereotyped or stagnant-so as to meet the needs of a changing world or society, and the present arrangement of the General Certificate of Education examinations owes much to the analysis of the Norwood Report of 1943. The vast impact of the sciences, pure and applied, during the post-war years, came a little too late for him to play an active part; but it might have been interesting indeed to see his outlook upon it.

Norwood had a strong, compelling, even if at times enigmatic personality. In appearance he might have been likened to Lord Kitchener, and the methods of the two men were at times similar. His deep religious beliefs were matched by a conviction of the essential correctness and desirability of his educa. tional policies. This caused him at times to appear despotic and ruthless. He brought criticism upon himself from some by the widespread publicity he gave to his ideas. Yet he did not deliberately seek the publicity which followed as a result of the innate conviction of his mission and his desire for progress. The value of his work was proved by the suceesses of his pupils and masters alike. His reserve, possibly a shyness, made him appear unapproachable to many ; but others learnt to know him as a kindly, human personality and friend of good counsel. Of all the talks which he gave throughout his life, few could have surpassed in simple, penetrating eloquence that which he delivered in the chapel of his College on the cessation of war in 1945. For him, too, it was to be the epilogue of a life filled with interest and achievement.

\section{Dr. Robert Pohi}

Over a period of fully half a century, developments in the design of rotating electrical machines have been influenced by the work of Dr. Robert Pohl, whose death occurred on March 15. He was seventyseven years of age.

Born at Hamm, Westphalia, Pohl received his university education at Hanover and his first industrial experience with the firm of Lahmeyer in Frankfurt. At the time at which Pohl entered the electrical industry, direct-current practice was well established and the utilization of alternating current was undergoing intensive development. The dynamo was already an efficient and relatively refined machine awaiting only the devising of means further to improve its commutation. Pohl's first contribution to the advancement of electrical knowledge, made when he was little more than a student, was towards elucidat. ing the mode of action of the interpole or commutating pole then newly invented.

Pohl went to England in 1904 to join the staff of the Phoenix Dynamo Co. of Bradford, and he was appointed chief engineer of the Company at the age of twenty-eight. He was responsible for the produetion by that Company of the first machine with commutating poles to be built in Great Britain. From 1905 onwards Pohl contributed, except for the period of the First World War, to the literature of electrical machinery. His more important early papers were on direct-current machines, but by 1914 he was writing on turbo-alternators.

Six months after the outbreak of the First World War Pohl was interned. He returned to Germany in 1919, where he became director and chief engineer of the A.E.G. Turbine Works in Berlin. More than thirty papers, published for the most part in ElektroTechnische Zeitschrift and Elektrotechnik und Maschinenbau between 1919 and 1938, record the contributions which placed Pohl in the first rank of designers of large electrical machines. He made one of the early experiments in the hydrogen cooling of alternators, running a machine in town's gas in Charlottenburg. By 1938 it had become clear to Pohl that he and his family could not much longer escape Nazi persecution. Through the good offices of friends he was able to get away safely to England and was joined by his wife and son. Prof. William Cramp was instrumental in securing the appointment of Pohl to the staff of his department in the University of Birmingham.

The third phase of Pohl's career was to prove no less fruitful than the first two. He brought to his teaching a wealth of practical experience, and he had the power to transmit his ideas. The British ThomsonHouston Co. retained him as a consultant, and it was not long before contributions from his pen began again to appear in the Journal of the Institution of Electrical Engineers. This time, inductor alternators and the behaviour of magnetic material in machines claimed much of his attention.

At the time of his retirement from the University of Birmingham Pohl was serving as a consultant in 